\begin{tabular}{|c|c|c|}
\hline $\begin{array}{l}\text { KULTURA } \\
\text { I } \\
\text { SPOLECZENS }\end{array}$ & $\begin{array}{l}\text { POLSKA AKADEMIA NAUK } \\
\text { KOMITET SOCJOLOGII } \\
\text { INSTYTUT STUDIÓW POLITYCZNYCH } \\
2015, \mathrm{nr} 4\end{array}$ & ISSN 0023-5172 \\
\hline
\end{tabular}

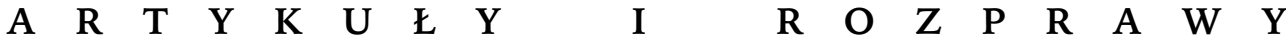

ŁUKASZ IWASIŃSKI

Uniwersytet Warszawski

\section{SPOŁECZEŃSTWO KONSUMPCYJNE W UJĘCIU ZYGMUNTA BAUMANA}

Czy w realiach pełzającego kryzysu ekonomicznego uprawnione jest nazywanie zachodnich społeczeństw konsumpcyjnymi? Wydaje się, że tak. Nie chodzi wszak tylko o skalę konsumpcji. Tym, co społeczeństwa te konstytuuje, jest totalność utowarowienia, komercjalizacja niemal wszelkich aspektów życia. A także - postrzeganie roli konsumenta jako podstawowej roli społecznej. Zdaniem Zygmunta Baumana, kryzys ujawnił siłę społeczeństwa konsumpcyjnego, jego presję. $\mathrm{W}$ tej presji socjolog widzi przyczyny zamieszek $\mathrm{w}$ angielskich miastach w sierpniu 2011 roku. U ich źródeł legła niemożność sprostania standardom życia narzucanym przez opisywany typ społeczeństwa. „To są rozruchy wybrakowanych i zdyskwalifikowanych konsumentów. [...] Od kołyski do trumny trenuje się nas i musztruje, abyśmy przyjmowali sklepy za apteki wypełnione medykamentami leczącymi, a przynajmniej łagodzącymi, wszelkie dolegliwości i bolączki własnego i wspólnego życia. [...] odsunięcie od zakupów jest jątrzącą i ropiejącą raną i upokarzającym brzemieniem niespełnionego życia, a zatem własnego niezgulstwa i niewydolności; braku nie tylko i nie tyle przyjemności, co ludzkiej godności i sensu życia. W ostatecznym rozrachunku - braku lub niedostatku człowieczeństwa i jakiejkolwiek innej podstawy do własnego do siebie szacunku jak i szacunku ze strony innych wokół" (Bauman 2011).

Wielu autorów odwołuje się do pojęcia społeczeństwa konsumpcyjnego, nie podając jednak jego kompleksowej charakterystyki. Wśród myślicieli, którzy proponują jego całościowy, konsekwentny portret, na największą uwagę zasługuje właśnie Bauman. Proponuje on najbardziej kompletne, a przy tym

Adres do korespondencji: lukiwas@gmail.com 
szalenie jaskrawe - lub wręcz przejaskrawione, lecz przez to nad wyraz obrazowo i dobitnie przemawiające do czytelnika - ujęcie interesującej nas formy społeczeństwa. Należy mieć na uwadze, że jego prace zawierają kategoryczne tezy, będące skrajnymi, jakby służącymi przestrodze, wnioskami wyciągniętymi $z$ zaobserwowanych zjawisk, procesów, tendencji, a nie skrupulatną i wyważoną ocenę. Dzięki temu konstrukt społeczeństwa konsumpcyjnego zyskuje na wyrazistości. Autor tłumaczy, że posługuje się metodą typów idealnych. „Typy idealne są [...] użytecznymi i niezastąpionymi narzędziami poznawczymi, nawet jeśli (a może właśnie ponieważ) skupiają światła na pewnych aspektach opisywanej rzeczywistości społecznej, pozostawiając w cieniu inne jej aspekty" (Bauman 2009a, s. 35) ${ }^{1}$. Przedstawiam tu najważniejsze, powracające w całym dorobku tego myśliciela wątki dotyczące tytułowego zagadnienia.

\section{SPOŁECZEŃSTWO KONSUMENTÓW VERSUS SPOŁECZEŃSTWO PRODUCENTÓW}

Koncepcja społeczeństwa konsumpcyjnego pojawia się u Baumana w wydanej w 1988 roku książce Wolność ${ }^{2}$ i jest obecna w zdecydowanej większości jego kolejnych, licznych prac, w których myśliciel ten ją rozwija, niekiedy umiejscawiając w centrum refleksji, a niekiedy czyniąc tłem dociekań. Przeciwstawia społeczeństwo konsumpcyjne (czy też społeczeństwo konsumenckie bądź społeczeństwo konsumentów) wcześniejszej formie - społeczeństwu producentów. Pierwsze wiąże z płynną nowoczesnością, a drugie z poprzedzającą je nowoczesnością — jak sam w różnych źródłach pisze — „stałą”, „stabilną”, „solidną”, „twardą”, „ciężką” ${ }^{3}$. Niektórzy autorzy, na przykład George Ritzer, nie stosują takiej dychotomii, łącząc społeczeństwo konsumpcyjne po prostu z rozwojem nowoczesności; choć dostrzegają wprowadzoną przez Baumana cezurę, to nie uznają jej za punkt początkowy organizacji nowego typu, lecz traktują jako wyraz ewolucji w obrębie istniejącego społeczeństwa konsumpcyjnego. Sam Bauman pisze, że różnica między omawianymi typami społeczeństw nie polega na prostej zamianie ról. „Ani na jednym, ani na drugim etapie swego

\footnotetext{
${ }^{1}$ Autor nawiązuje tu, rzecz jasna, do Weberowskiej kategorii typów idealnych (Weber 1985, s. 81-90).

2 Ściślej - pojawiają się tam sformułowania „społeczeństwo konsumenckie” oraz „społeczeństwo konsumentów" (Bauman 1995, s. 86, 103-105). W niektórych pracach Bauman posługuje się też pojęciem społeczeństwa konsumpcyjnego. Być może jest to kwestia innego tłumaczenia tego samego zwrotu.

${ }^{3}$ Fazę nowoczesności, wiązaną ze społeczeństwem producentów, Bauman różnie określa w różnych książkach — „stała” bądź „stabilna” czy „solidna” (w Konsumowaniu życia), „twarda” (w Ptynnym życiu) czy „ciężka” (heavy) (w Individualized Society). Przeciwstawia ją, powiązanej ze społeczeństwem konsumentów, fazie „płynnej” (która to nazwa jest bliskoznaczna, jeśli nie synonimiczna $z$ „drugą fazą nowoczesności”, "późną nowoczesnością” i „ponowoczesnością”). Nie wskazuje przy tym jednoznacznej daty oddzielającej wyszczególnione fazy nowoczesności i tym samym typy społeczeństwa.
} 
rozwoju społeczeństwo nowoczesne nie mogło obejść się bez tych, którzy produkują przeznaczone do konsumpcji rzeczy; oczywiście członkowie obu tych społeczeństw też konsumują. Różnica między dwiema fazami nowoczesności polega «jedynie» na tym, co jest priorytetem i na co kładzie się największy nacisk. Jednak to przesunięcie nacisku spowodowało ogromne różnice w każdej praktycznie dziedzinie życia społecznego, kulturalnego i życia jednostki. Różnice są tak głębokie i wielopostaciowe, że mamy pełne prawo traktować nasze społeczeństwo jako formację innego rodzaju — społeczeństwo konsumpcyjne" (Bauman 2000a, s. 95-96).

W interpretacji socjologa społeczeństwo producentów charakteryzowało się tym, że praca była w nim „osią życia jednostki”, „głównym punktem orientacyjnym, w odniesieniu do którego można było planować i porządkować wszystkie inne zajęcia życiowe" (Bauman 2006a, s. 42-43) Stanowiła kluczową składową tożsamości, a przede wszystkim determinowała status, miejsce $\mathrm{w}$ hierarchii społecznej. W społeczeństwie producentów to „praca była głównym wyznacznikiem zarówno tożsamości społecznej, jak i samooceny. Wyjąwszy tych, którzy dzięki odziedziczonemu bądź zdobytemu bogactwu mogli połączyć nieróbstwo z samowystarczalnością, na pytanie: kim jesteś?, wszyscy odpowiadali, wskazując na miejsce pracy i zajmowane stanowisko [...], rodzaj pracy stanowił decydującą, kluczową klasyfikację, z której wywodziły się wszystkie pozostałe, istotne dla życia pośród innych" (Bauman 2006a, s. 42-43). W społeczeństwie konsumpcyjnym analogiczną rolę zaczyna pełnić konsumpcja. Społeczeństwo konsumentów „interpeluje swych członków (czyli zwraca się do nich, wywołuje ich, wzywa, bada i ocenia, ale też przerywa im i wtrąca się do ich poczynań) przede wszystkim w ich modalności konsumentów [...]. Społeczeństwo ocenia - nagradza lub karze - swoich członków zależnie od skwapliwości, z jaką odpowiadają na interpelacje i stopnia poprawności odpowiedzi" (Bauman 2009a, s. 61). Ułomność w sferze konsumpcji, bycie konsumentem niewydajnym, wadliwym, staje się tym samym podstawowym czynnikiem wykluczenia społecznego. „Konsumować więc to tyle, co inwestować we własne członkostwo w społeczeństwie" (Bauman 2009a, s. 65).

\section{IMPERATYW WYBORU}

Porządek społeczeństwa producentów był oparty na silnej normatywnej regulacji, funkcjonowanie $\mathrm{w}$ jego ramach wymagało znacznego konformizmu. Modelem panujących w nim relacji i ładu społecznego była fabryka. Bauman (2006a, s. 44) stwierdza wręcz, iż produktem fabryki był nie tylko określony towar, ale także (a nawet przede wszystkim) „uległy poddany nowożytnego państwa”. Społeczeństwo producentów „przysposabiało swych członków do pracy w przemyśle i służby $\mathrm{w}$ wojsku. W związku $\mathrm{z}$ tym krzewiono i pielęgnowano takie cnoty, jak posłuszeństwo, konformizm i zdolność do mozolnej pracy i monotonnej rutyny. Wśród wad, które należało wytępić, znalazły się natomiast 
fantazja, pasja, duch buntu i niechęć do kroczenia w szeregu" (Bauman 2007b, s. 174). Społeczeństwo produkcyjne było zarządzane przez instytucje panoptyczne. Panoptykon to projekt doskonałego więzienia, w którym skazańcy cały czas mogą być obserwowani przez strażników, choć sami nie wiedzą, czy i kiedy są podglądani. W humanistyce pojęcie to funkcjonuje jako symbol doskonałego nadzoru, opartego na permanentnej obserwacji (Foucault 1993, s. 241-242; Bauman 1995, s. 14-35). Ostatecznym celem instytucji panoptycznych jest wprowadzenie idealnej regulacji normatywnej, skutkującej absolutnym, opartym na uwewnętrznionej kontroli posłuszeństwem. Instytucje takie nadawały się do „wdrażania ludzi do rutynowych, monotonnych zachowań i osiągały ten rezultat poprzez ograniczanie bądź całkowitą eliminację wyboru" (Bauman 2006a, s. 56). Jednakże w społeczeństwie konsumentów to właśnie „brak rutyny i ustawiczne dokonywanie wyboru stanowią cnoty (a w rzeczy samej wstępne wymogi roli) konsumenta" (Bauman 2006a, s. 56). Z takim społeczeństwem „panoptyczny dryl” nie da się pogodzić. „Panoptyczne metody drylu w sposób oczywisty byłyby skierowane przeciw istocie konsumpcyjnych celów i okazałyby się zabójcze dla społeczeństwa zorganizowanego wokół pragnienia i wyboru" (Bauman 2006a, s. 62).

W społeczeństwie konsumentów idea regulacji normatywnej — spełniająca swe zadanie jako narzędzie dyscyplinowania pracowników - traci zatem na znaczeniu. W sferze zarządzania konsumentami staje się ona kontrefektywna. Im bardziej ścisłe są normy, tym większe ograniczenie wolności wyboru, możliwości folgowania swoim chwilowym zachciankom, ulotnym kaprysom, co stanowi, zdaniem Baumana, siłę napędową rynku i tym samym społeczeństwa konsumpcyjnego. Społeczeństwo konsumpcyjne gloryfikuje indywidualizm, samostanowienie, autokreację, a jego systemowym wymogiem stają się nieustanne wybory (Bauman 2009a, s. 67-70). „Sam nakaz dokonywania samodzielnych wyborów i uznawania każdego działania za skutek samodzielnego, swobodnego wyboru z całą pewnością nie jest już kwestią swobodnego wyboru" (Bauman 2007b, s. 37). Jednak konsumentowi nie jawi się on jako przymus, lecz podstawowe prawo. Chce on mieć, jeśli nie nieograniczony, to szeroki i cały czas poszerzający się wybór, jeśli nie we wszystkich, to w większości obszarów życia (od dóbr materialnych przez szeroko pojęty styl życia i miejsce życia po własną tożsamość). Zatem stale podejmuje on wybory zarówno jako podmiot konsumpcji (a więc musi decydować, co i jak chce konsumować), jak i jako jej przedmiot (innymi słowy decydować musi, jak ma stworzyć siebie $z$ dostępnych na rynku produktów i jak się za ich pomocą atrakcyjnie przedstawić). Wolność i obfitość wyboru staje się zarazem kluczowym czynnikiem stratyfikacyjnym (Bauman 2006a, s. 71, 80): „ustanawia hierarchię społeczeństwa konsumpcyjnego oraz ramy, w które jego członkowie, konsumenci, wpisują swoje aspiracje życiowe [...]. Im większą ma się wolność wyboru, a przede wszystkim im więcej wyborów swobodnie się dokonuje, tym wyższe miejsce zajmuje się w społecznej hierarchii, na tym większy szacunek 
innych i własny można liczyć" (Bauman 2006a, s. 66). Pieniądze ważne są o tyle, o ile powiększają możliwości konsumenta w tym zakresie. Bogactwo samo w sobie nie jest podstawą stratyfikacji.

Nowoczesne społeczeństwo producentów wierzyło zatem, że do podtrzymania wspólnoty i rozwoju społecznego jest niezbędne wdrożenie systemu normatywnego służącego tłumieniu jednostkowych instynktów. Sądzono - co doskonale opisali choćby Zygmunt Freud czy Michel Foucault - że reprodukcja społeczeństwa musi być oparta na represji i indoktrynacji, co więcej, że ich natężenie zwiększa się wraz z postępem cywilizacyjnym. Powoduje to narastający konflikt między - mówiąc językiem Freuda - zasadą przyjemności a zasadą rzeczywistości. Okazało się jednak, że w realiach bazującego na rynkowej regulacji porządku społeczeństwa konsumentów poszerzenie swobody działań jednostek nie przyczynia się do destrukcji systemu. Wyzwolone, mogące śmiało schlebiać swym kaprysom jednostki po prostu są bardziej wydajnymi konsumentami. W rozwiniętym społeczeństwie konsumpcyjnym zawalił się więc, a w każdym razie został naruszony, wysoki i, jak wcześniej sądzono, mający wciąż rosnąć mur między zasadą przyjemności a zasadą rzeczywistości. W mocy jest teraz „zasada realności”, która wymaga „spełniania obowiązku dążenia do przyjemności i szczęścia", a realizowana jest poprzez rynkowe wybory i doświadczana jako „wyraz wolności i akt samostanowienia” (Bauman 2009a, s. 83 ; 2006b, s. 216).

Trzeba podkreślić, iż zarządzanie przez poluzowanie normatywnych gorsetów i promocję wolnego wyboru pozwala władzy (która należy przede wszystkim do rynku, co dalej zostanie szerzej omówione) na głębszą kontrolę poddanych (konsumentów). Po prostu władza taka jawi się jako mniej bolesna (albo zupełnie bezbolesna), niedokuczliwa, nie budzi więc oporu i konsumenci chętnie jej się podporządkowują.

\section{TOTALNOŚĆ UTOWAROWIENIA}

Społeczeństwo konsumpcyjne jest konstytuowane raczej nie przez zwiększenie się skali konsumpcji, a już na pewno nie przez dominację postawy materialistycznej. Zjawiska te mogą w nim występować, ale są wtórne wobec fenomenu zasadniczego - totalności utowarowienia albo, mówiąc nieco inaczej, wszechobecnej, przenikającej wszelkie aspekty życia komercjalizacji, czy też jeszcze inaczej — omnipotencji rynku. Społeczeństwo konsumpcyjne w swym typie idealnym - a jak przestrzega Bauman, świat zachodniego kapitalizmu do tego modelu zmierza - wszelkie elementy rzeczywistości usiłuje sprowadzić do dóbr konsumpcyjnych (towarów). Wchłania obszary, które niegdyś pozostawały poza obrotem towarowym, asymiluje nawet wszelkie formy sprzeciwu wobec tej tendencji (Bauman 2009a, s. 56). „Rynek konsumpcyjny to współczesna (oczywiście zmutowana) wersja spełnionego snu króla Midasa. Wszystko, czego dotyka rynek, zamienia się natychmiast w towar konsumpcyjny. Doty- 
czy to także tych rzeczy, które próbują wymknąc się reżimowi rynku, a nawet sposobów i środków, za pomocą których to czynią" (Bauman 2007b, s. 140). Totalizacja życia przez rynek jest stałym motywem twórczości omawianego tu autora. „Drogi do osobowej tożsamości, do miejsca w społeczeństwie, do form życia rozpoznawalnych jako sensowne - wszystko to domaga się codziennych odwiedzin rynku" (Bauman 2006a, s. 58). W zgodzie z tą diagnozą pozostaje zaobserwowane przez badaczy postępujące zawłaszczanie przez konsumpcję czasu wolnego. Kategorie te stają się coraz bardziej zbieżne, jeśli nie tożsame. Zjawisko to nosi nazwę monetaryzacji czasu wolnego ${ }^{4}$, a towarzyszy mu rozrost rynku czasu wolnego, oferującego ,towary umożliwiające wykorzystanie i spędzenie czasu wolnego" (Bombol, Dąbrowska 2003, s. 50).

Marek Krajewski (1997, s. 15) zauważa, iż wszystko, co tylko ,jest w stanie zwrócić uwagę klienta, może stać się towarem - patologie, ludzkie nieszczęścia i tragedie, ale też wartości duchowe, tradycja, tzw. osobowości i indywidualności czy życie rodzinne i prywatność". Można by rzec, że tylko te dziedziny życia, które podlegają konsumpcji (innymi słowy — te które zostały utowarowione), mogą społecznie zaistnieć. Te natomiast sfery życia człowieka, które z jakichś względów nie mogą poddać się temu procesowi, a więc wymykają się komercjalizacji, są wyrzucane poza nawias życia społecznego. Przedmiotem konsumpcji staje się także sam człowiek, w tym sensie, że jego relacja do własnego ciała i tożsamość kształtowana jest poprzez rynek (oferuje on materiały do stwarzania i prezentowania siebie, często także narzuca w tym zakresie standardy i udostępnia służące sprostaniu temu narzędzia), a także w tym sensie, że w coraz większym stopniu przez rynek zapośredniczone są relacje z innymi. Ten fenomen obrazowo ukazują następujące cytaty: „Członkowie społeczeństwa konsumentów są sami towarami konsumpcyjnymi i ta właśnie właściwość czyni ich bona fide członkami społeczeństwa” (Bauman 2009a, s. 66); „W społeczeństwie konsumentów nikt nie może stać się podmiotem, nie zmieniając się najpierw w towar, nikt też nie może utrzymać swego upodmiotowienia, nie reanimując, nie wskrzeszając i nie uzupełniając nieustannie zdolności, jakich się oczekuje i wymaga od sprzedawanego towaru. Podmiotowość podmiotu oraz większość tego, co taka podmiotowość pozwala podmiotowi osiągnąć, skupia się na nieustannym wysiłku, by samemu stać się i pozostać sprzedawalnym towarem" (Bauman 2009a, s. 18).

W społeczeństwie konsumpcyjnym podmiotowość uzyskuje się więc, po pierwsze, przez efektywne wywiązywanie się z konsumpcyjnego obowiązku, po drugie, przez stawanie się, czynienie siebie samego atrakcyjnym, pokupnym towarem. Im bardziej konsument dąży do upodmiotowienia, tym bardziej musi zostać uprzedmiotowiony - oto zagadka dialektyki podmiotu i przedmiotu

\footnotetext{
${ }^{4}$ Choć na miejscu byłyby również określenia: komercjalizacja, utowarowienie bądź (będąca dokładnym odpowiednikiem tego ostatniego, a stanowiąca spolszczoną wersję angielskiego commodification) komodyfikacja czasu wolnego.
} 
społeczeństwa konsumpcyjnego. W myśl powyższych rozważań prawdziwe jest więc nie tylko zdanie: konsumuję więc jestem (pełnoprawnym członkiem społeczeństwa), ale także: jestem konsumowany, więc jestem (pełnoprawnym członkiem społeczeństwa). Człowiek, który nie potrafi sprostać tym wymogom, staje się bezużyteczny dla społeczeństwa konsumpcyjnego - ta właśnie cecha, bycie nie-konsumentem i nie-towarem, jest atrybutem przynależności do podklasy, niezależnie od wszelkich innych właściwości społecznych, kulturowych, demograficznych (Bauman 2006a, s. 132-135). Wszelkie możliwe cnoty, kompetencje, intelekt na nic się zdadzą, jeśli nie przełożą się na zdolność samoutowarowienia i konsumowania.

W zindywidualizowanym społeczeństwie konsumentów winę za znalezienie się $\mathrm{w}$ tej haniebnej grupie ponosi sama jednostka. Rynek daje wszystkim szanse (a raczej taką buduje iluzję), nie wymaga podporządkowania się żadnej ideologii; jednym słowem, nikogo nie wyklucza ${ }^{5}$. Zdaje się mówić: jeśli jesteś na marginesie - wykluczyłeś się sam, z własnej woli, a więc nie licz na pomoc. W tym pozostawieniu przegranych samym sobie widzi Bauman główne zarzewie przestępczości i, w typowym dla siebie stylu, doprowadzając tę tezę do skrajności, stwierdza: „więzienia zastępują ograniczane i stopniowo likwidowane instytucje opieki społecznej i będą prawdopodobnie musiały przystosować się coraz bardziej do tej nowej funkcji, w miarę jak świadczeń społecznych będzie ubywać" (Bauman 2009a, s. 141). Wszechobecne nawoływania do „bycia sobą”, wolności w projektowaniu własnego życia, pogłębiają poczucie bezsilności, podkupują wiarę $\mathrm{w}$ siebie i frustrację tych, którzy nie są $\mathrm{w}$ stanie owych postulatów realizować. Wadliwych, a więc niezdatnych, zdyskwalifikowanych przez społeczeństwo, konsumentów nie da się fizycznie wyeliminować - co byłoby na swój sposób powtórzeniem logiki faszyzmu, według Baumanowskiej, biurokratycznej interpretacji, trzeba więc ich przynajmniej usuwać z miejsc konsumpcji, gdyż kalają je samą swą obecnością, i izolować (Bauman 2000b, s. 29-31). Członkowie podklasy jawią się (i tak też są w społeczeństwie konsumpcyjnym przedstawiani) jako kategoria nie tylko (w zasadzie) zbędna, ale i niebezpieczna - są wszak niczym piasek sypany w tryby rynkowego obrotu, spowalniają go, powodują, że się zacina. Dlaczego „w zasadzie”? Ponieważ jedna funkcja uzasadnia ich obecność. Podklasa stanowi przestrogę dla innych, prawdziwych konsumentów - by nigdy nie zapomnieli o swych zobowiązaniach społecznych. Dlatego „stanie się i pozostawanie sprzedawalnym towarem jest najobfitszym źródłem niepokoju konsumentów, nawet jeśli zazwyczaj pozostaje w ukryciu i nie dociera do świadomości" (Bauman 2009a, s. 66). A zatem to, co nie zostało utowarowione, nie ma racji bytu, a inny

\footnotetext{
${ }^{5}$ To twierdzenie - że rynek oraz oparte na nim współczesne neoliberalne demokracje stanowią płaszczyznę równoprawnej partycypacji, nikogo nie wykluczając - jest podważane przez Baumana (szerzej zob. Bauman 2004). Stanowi ono przedmiot krytyki najważniejszych środowisk współczesnej lewicy.
} 
niż towarowy stosunek do rzeczywistości powinien zdradzać brak kompetencji i profesjonalizmu, powinien budzić nieufność. „Rynek uparcie przypomina, że wszystko jest lub może stać się towarem, a to, co nim jeszcze nie jest, powinno być traktowane jakby było towarem. Rzeczy nie przystające do roli przedmiotu konsumpcji powinny wzbudzać podejrzliwość. Należy pozbyć się ich od razu, a najlepiej unikać jak ognia" (Bauman 2007b, s. 139). Odnosi się to nie tylko do przedmiotów, ale także do ludzi.

Funkcjonujący w takim systemie konsument nabiera przekonania, że receptę na wszelkie problemy, jakich nastręcza życie, zawsze znajdzie na rynku. Tak oto cała jego egzystencja „orientuje się na rynek, każde pragnienie i każdy wysiłek wiążą się z poszukiwaniem możliwych do nabycia narzędzi lub przepisów. W ten sposób zadanie ułożenia całości życia [...] rozbite zostaje na wielość aktów kupna" (Bauman 1996, s. 210-211). Rynek jest więc w społeczeństwie konsumpcyjnym podstawowym regulatorem życia społecznego. W swym radykalizmie Bauman stwierdza, że ta forma regulacji poprzedza wszelkie inne, jak choćby prawo (Bauman 2009a, s. 71-72; 2000b, s. 46).

Siła rynku przewyższa zatem, czy też poprzedza, regulatywną moc prawa, ideologii (np. patriotyzmu), polityki ${ }^{6}$. Bauman rozważa przykład deportacji emigrantów we współczesnych państwach zachodnich (konkretnie analizuje przypadek Francji). Decyzja o wykluczeniu określonych osób, choć polityczna, oparta była jednak na kryteriach ekonomicznych, one okazały się pierwotne. „Selekcji wstępnej dokonały siły pozapolityczne, nad którymi państwo nie sprawuje kontroli (przyznawanie prawa stałego pobytu i skazywanie na deportację jest bowiem wielce subiektywne; ci spośród obcych, którzy gotowi są własnym potem oliwić tryby konsumpcyjnej machiny, mogą z reguły liczyć na specjalne względy)” - pisze Bauman (2007b, s. 158-159). A w innym miejscu: „Państwo jako całość, włączając $w$ to organa ustawodawcze i sądownicze, staje się organem wykonawczym rynkowego suwerena" (Bauman 2009a, s. 75). Tak oto, dobitnie, acz niewątpliwie nadmiernie jednostronnie, Bauman kwituje rolę państwa $\mathrm{w}$ społeczeństwie konsumpcyjnym. Według niego to rynek jest w społeczeństwie konsumpcyjnym podstawową, acz zupełnie abstrakcyjną, bezosobową instytucją władzy. Przez swą abstrakcyjność i bezosobowość wła-

${ }^{6}$ Ciekawym przyczynkiem do twierdzenia o wypieraniu ideologii i polityki przez rynek może być także słynny skok ze spadochronem z 39 km wykonany 14 października 2012 r. przez Felixa Baumgartnera, który ustanowił w ten sposób wiele rekordów, w tym wysokości i prędkości spadania. Niegdyś tak ogromne projekty były organizowane i finansowane przez państwa i miały wymiar zdecydowanie polityczny (jak choćby lądowanie człowieka na Księżycu). Dziś wielkie, (dosłownie) kosmiczne przedsięwzięcia coraz częściej są aranżowane i opłacane przez potężne korporacje i mają wymiar nade wszystko komercyjny. Fakt ten nie poddaje się jednoznacznej ocenie. Jedni ubolewać będą, że spektakularne projekty, które powinny służyć bezinteresownemu poznaniu i rozwojowi, ewentualnie chwale ojczyzny, ulegają komercjalizacji. Inni stwierdzą, że bezinteresowne nigdy one nie były, a fakt, iż kiedyś stanowiły narzędzie walki politycznej ( $w$ tym element programu wyścigu zbrojeń), a dziś są podpinane pod marketingowe kampanie, nic im nie ujmuje, a nawet prezentuje je w korzystniejszym świetle. 
śnie (albo też niewidzialność, by odwołać się do metafory Adama Smitha) wydaje się bardziej bezwzględny i kategoryczny niż jakikolwiek organ polityczny czy jakakolwiek inna formalna władza.

\section{POCHWAŁA PRZEMIJALNOŚCI}

Ważnym, silnie akcentowanym przez Baumana zjawiskiem występującym w społeczeństwie konsumpcyjnym jest wszechobecna pochwała przemijalności i pogarda wobec trwania ${ }^{7}$. To odwrócenie porządku wartości panującego w społeczeństwie producentów (Bauman 2009a, s. 94; 2007a, s. 6-9). Wynika ono z prostego faktu — krótkotrwałość produktów jest dla systemu opłacalna, bo prowadzi do ich szybszej wymiany na nowe, a więc zwiększenia obrotu rynkowego i tym samym intensyfikacji konsumpcji. „Rynek konsumpcyjny zaleca szybką cyrkulację towarów, skracanie dystansu między użytkowaniem a pozbywaniem się przedmiotów i błyskawiczną wymienność rzeczy" — pisze Bauman (2007b, s. 94). A gdzie indziej stwierdza: „Skracanie życia produktu i uznanego okresu jego użyteczności stanowi element strategii rynkowych i kalkulacji zysków. Planuje się je z góry i wpaja konsumentom przez apoteozę nowych (dzisiejszych) propozycji i dewaluowanie dawnych (wczorajszych)" (Bauman 2009a, s. 27). W podobnym tonie pisał Jean Baudrillard (2006, s. 41-42): „Wiadomo przecież, że porządek produkcji utrzymuje się jedynie za cenę owej eksterminacji, owego nieustannego wykalkulowanego samobójstwa masy przedmiotów, wiadomo, że operacja ta opiera się na technologicznym sabotażu lub zorganizowanym wychodzeniu z użycia i starzeniu się przedmiotów, a wszystko to pod znakiem mody".

Proces ten przekłada się na wiele wymiarów życia społecznego — od psychologii konsumentów (skraca się dystans między rozkwitem a wygaśnięciem pożądania) po kulturę (skróceniu ulegają wszelkie mody, trendy). W społeczeństwie konsumpcyjnym mamy więc do czynienia ze stymulowaną przez rynek kulturową akceleracją, dla której granicę stanowią chyba tylko możliwości percepcyjne człowieka, bo musi on być w stanie nadążać za zmianami, monitorować je i dostosowywać się do nich, by napędzać konsumpcję. Nieprawdą jest zatem, że członkowie społeczeństwa konsumpcyjnego „tęsknią przede wszystkim za zawłaszczeniem, posiadaniem, gromadzeniem przedmiotów” (Bauman 2009a, s. 36-37). Te motywy wiąże Bauman ze społeczeństwem producentów, którego członkowie cenili stabilizację, długofalowe bezpieczeństwo. Realizację tych aspiracji zapewniała właśnie trwała własność. Wymogi systemu w społeczeństwie konsumentów narzucają zgoła odmienne dążenia. „Najlepiej, by konsument nie chwytał się niczego mocno. [...] Tym co się liczy, jest zmienność" (Bauman 2006a, s. 56).

7 Zjawisko to bywa określane mianem „instantyzacji” (Mróz 2009, s. 20). 
Proces zasypywania rynku nowymi towarami musi nieustannie trwać, ich ruch, cyrkulacja nie może ustać. „Jeśli zaraz po przebudzeniu połączysz się ze swoim serwerem ${ }^{8}$ — pisze Bauman (2007b, s. 18) — przypomni ci o tej prostej prawdzie pierwsza wiadomość, jaka wyświetli się na twoim ekranie: Wstydzisz się swojej komórki? Twój telefon jest tak stary, że czujesz się skrępowany, gdy z niego korzystasz? Spraw sobie nowoczesny aparat, z którego będziesz dumny”. Owo zalecenie pociąga za sobą zakaz „pokazywania się z aparatem, który sprawiłeś sobie poprzednim razem". Funkcjonalne dla systemu jednostki powinny być zatem podatne na coraz to nowe podniety, a zarazem szybko tracić zainteresowanie tym, co jeszcze przed chwilą stanowiło dla nich źródło ekscytacji. Benjamin Barber (2008, s. 20, 42) twierdzi, że sprzyja temu postępujący proces infantylizacji konsumentów - stają się oni, niczym dzieci, niecierpliwi i spontaniczni, każdą zabawkę chcą mieć natychmiast. Członków społeczeństwa konsumpcyjnego charakteryzuje więc: „niestabilność pragnien” i „skłonność do natychmiastowej konsumpcji i natychmiastowego pozbywania się jej przedmiotów" (Bauman 2009a, s. 39). Dlatego nad potrzebą zawłaszczania i gromadzenia towarów zaczyna dominować potrzeba (czy wręcz przymus) ich pozbywania się i zastępowania. Można wręcz rzec, zgodnie z prezentowaną przez Baumana (a powtórzoną za Baudrillardem) logiką, że reprodukcja społeczeństwa konsumentów bazuje nie na tworzeniu trwałej wartości, ale na marnotrawieniu. Im gwałtowniejszy zanik, anihilacja przedmiotów konsumpcji, tym lepsze perspektywy rozwoju (Baudrillard 2006, s. 43). W tak zorganizowanym społeczeństwie figurą bohatera zostaje „wielki marnotrawca”. W tej roli występują najczęściej gwiazdy popkultury „stanowiące ucieleśnienie zbytkownego, bezcelowego i rozbuchanego wydatkowania" (Baudrillard 2006, s. 41). Historie o nich zastąpiły niegdysiejsze przypowieści o „bohaterach produkcji” czy, wcześniejsze, żywoty świętych.

Jak zauważa Lesław Hostyński (2006, s. 108), coraz więcej firm z coraz większej liczby sektorów oferuje nowy produkt po niższej cenie pod warunkiem zwrotu starego. Warto odnotować, że dziś niejednokrotnie firmy proponują nie tylko dowiezienie nabytego towaru do domu klienta, ale także posprzątanie starych, które ów zakup ma zastąpić. „W społeczeństwie płynnej nowoczesności przemysł związany $z$ usuwaniem i przetwarzaniem odpadów przejmuje wiodącą rolę w kształtowaniu ekonomicznych podstaw płynnego życia. Przetrwanie tego społeczeństwa i pomyślność jego obywateli zależą od łatwości, z jaką jego produkty trafiają na śmietnik oraz od tempa i sprawności pozbywania się odpadów" (Bauman 2007b, s. 8).

Ideę tę wykorzystują nawet serwisy ogłoszeniowe, które $\mathrm{w}$ swych reklamach podkreślają wcale nie możliwość znalezienia i zaopatrzenia się za ich pośrednictwem w interesujący nas towar, lecz pozbycia się zbędnych arty-

8 Trzeba sprostować - przeciętny użytkownik internetu raczej nie łączy się ze „swoim serwerem”, a z określoną stroną, której zawartość znajduje się na określonym serwerze. 
kułów. Na przykład telewizyjnej reklamie serwisu Gumtree, przedstawiającej młodego mężczyznę $\mathrm{w}$ pokoju zastawionym najróżniejszymi produktami, towarzyszy następujący tekst: „To jest Maciek. Maciek chce pozbyć się rzeczy. Nie ma problemu Maćku, możesz natychmiast pozbyć się wszystkiego na Gumtree. Za darmo. Gumtree.pl - bezpłatne ogłoszenia lokalne" ${ }^{9}$. W Stanach Zjednoczonych istnieje nawet zawód specjalisty od usuwania zbędnych przedmiotów. „Gwiazdą w tym fachu jest Julia Morgenstern, która często występuje w talk show Oprah Winfrey. Pomniejsze gwiazdy prowadzą popularne reality shows, na przykład The Clean Swee ("Zmiatamy do czysta»), podczas których domy uczestników oczyszczane są na przyjęcie nowych zakupów. Foliowy worek na śmieci stanowi zresztą konieczny element wielu programów telewizyjnych typu makeover, czyli "transformacja». Czy zmieniamy styl ubierania się (What Not to Wear, czyli "Czego nie nosić»), czy też zarówno wygląd, jak i osobowość (Date Patrol, czyli «Patrol randkowy»), spora część nagromadzonych dóbr musi najpierw wylądować w koszu. Popularnością cieszą się poradniki uczące trudnej sztuki wyrzucania śmieci, takie jak: Let Go of Clutter («Pozbądź się gratów») czy bestselerowy Clear Your Clutter with Feng Shui («Pozbądź się gratów za pomocą feng-shui»)” (Grzeszczyk 2004, s. 127). Bauman (2007b, s. 132) konstatuje: „Dojrzali konsumenci bez specjalnego trudu rozstają się z rzeczami [...]. Bez żalu, a czasem z ledwie skrywaną ulgą akceptują krótki żywot przedmiotów i ich wiadomy koniec. Najzdolniejsi i najbystrzejsi adepci sztuki konsumpcji potrafią czerpać przyjemność z pozbywania się rzeczy, których okres przydatności (czytaj: atrakcyjności) bezpowrotnie przeminął".

Rynek robi co może, by usunąć wszelkie możliwe przeszkody chcącym wymienić swe produkty. W społeczeństwie konsumpcyjnym nie chodzi o to, by „mieć". Zarazem wcale nie o to w nim również chodzi, by „być”. Zarówno to, co jest przedmiotem posiadania - rzeczy materialne, jak i to, co stanowi o byciu - własna tożsamość i relacje z innymi ludźmi, tak samo muszą podlegać procesowi ciągłej wymiany ${ }^{10}$. „Tożsamości, podobnie jak dobra konsumpcyjne, należy przyswoić i posiąść, ale tylko po to, by zostały skonsumowane i ponownie znikły" (Bauman 2006b, s. 63). Pozornie ostry spór między (niskim, często potocznie kojarzonym z konsumpcjonizmem) posiadaniem a (szlachetnym, będącym zaprzeczeniem postawy konsumpcjonistycznej) byciem okazuje się drugorzędny. Społeczeństwo konsumpcyjne uderza w ich wspólną, przeczącą jego zasadom podstawę - trwanie (i nie jest ważne, czy chodzi o trwanie przedmiotów fizycznych, czy też wartości i postaw bądź związków z innymi). „I tak odpadła podstawa tradycyjnej opozycji między po-

\footnotetext{
${ }^{9}$ Reklama emitowana $\mathrm{w}$ telewizji w drugiej połowie 2011 roku, dostępna także na serwisie Youtube (http://www.youtube.com/watch?v=e0jni63D4Kk).

10 Buman (2007b, s. 55) pisze o „trwale nietrwałym ja”. Jak tłumaczy — jedynym „jądrem tożsamościowym” jest homo eligens — „człowiek wybierający (ale nie człowiek, który wybrał)”.
} 
siadaniem a byciem. Żadna z opcji nie wydaje się szczególnie atrakcyjna; obie odpychają i skłaniają do unikania ich. Obie zapowiadają zależność [...], a zależność to stan, z którego za wszelką cenę należy się wyrwać" (Bauman 2006b, s. 176-177).

Z powyższych powodów zapominanie staje się nie mniej, a może nawet bardziej pożądane od zapamiętywania — produkty (a także tożsamości) powinny być szybko wymazywane $z$ pamięci, by zrobić miejsce dla nowych; zresztą nietrudno o to $\mathrm{w}$ dobie tak zmasowanego zalewu informacją. A więc kultura społeczeństwa konsumpcyjnego nie jest kulturą akumulacji i ciągłości, lecz raczej fragmentaryzacji i zapomnienia (Bauman 2007b, s. 99). Ów proces „oczyszczania” pamięci ułatwia pracę kreatorom konsumenckich nowinek. Zamiast wymyślać oryginalne rzeczy mogą oni bazować na mniej lub bardziej dosłownych zapożyczeniach z przeszłości. Zjawisko tak pojętego kulturowego recyclingu można zaobserwować w przemyśle kulturowym pod postacią mód na najróżniejsze style czerpiące $z$ przeszłości ${ }^{11}$, Zdaniem Baumana zatem pogoń za nowością to naczelna zasada konsumenckiej poprawności. „Rynek nie przetrwałby, gdyby nabywcy przywiązywali się do rzeczy. Jego żywotny interes nie pozwala mu tolerować wiernych i lojalnych klientów ani tych, którzy trzymając się konsekwentnej i spójnej linii postępowania, nie schodzą z raz obranej drogi” (Bauman 2007b, s. 56). Autor ten uznaje, że wszelka trwałość, tradycja, ciągłość, lojalność stały się ofiarami społeczeństwa konsumpcyjnego (Bauman 2007b, s. 94). Lojalności należy się wstydzić — powiada, ale przemilcza fakt, że lojalność może być przecież także zjawiskiem nader dla konsumpcji funkcjonalnym - jest ona wręcz kluczowym aspektem wydajnej ekonomicznie relacji z konsumentem, pielęgnowanym $z$ tego powodu przez rynkowych graczy (Smyczek, Sowa 2005, s. 73-83). Ponadto w wielu sektorach rynku tradycja ma swą cenę - staje się rękojmią jakości: na niej budowana jest marka i bazuje — pokreślę, jakże ważna dla efektywnej sprzedaży — lojalność. Trzeba też zauważyć, że do najdroższych przedmiotów konsumpcji wciąż należą antyki i kanoniczne dzieła sztuki. Te kilka przykładów skłania do wniosku, że Bauman, przy całej sugestywności i w wielu punktach trafności wywodu, przecenia ów dyktat zmienności, przelotności i ostracyzm wobec wszelkiej trwałości we współczesnym społeczeństwie konsumpcyjnym ${ }^{12}$.

\footnotetext{
11 W konsekwencji to, co sprzedawane jest jako nowość, w istocie bazuje na kulturowym recyclingu. Fenomenowi temu poświęcił książkę Simon Reynolds (2011), krytyk i analityk muzycznej (popowej i alternatywnej) sceny ostatnich dwóch dekad.

12 Piotr Siuda, zwracając uwagę na ową pochwałę przemijalności i wszechobecną fetyszyzację nowości w społeczeństwie konsumpcyjnym, jednocześnie wskazuje na rozwój tendencji przeciwnej - mianowicie kolekcjonerstwa. „Zbieranie - jak pisze (Siuda 2012, s. 73) - jest aktem przeciwstawnym szybkiej konsumpcji, i to na wielu płaszczyznach. Pozwala wyrwać się z kołowrotu ciągłego nabywania i usuwania rzeczy, promuje ich zatrzymywanie, a nie niszczenie. Opór wobec presji producentów, chcących skompresować każdą wolną chwilę konsumenta oraz maksymalnie ją zekonomizować, przejawia się w selektywnym wyborze przedmiotów, które kolekcjoner nabywa".
} 


\section{PERMANENTNE NIEZASPOKOJENIE}

Fundamentalna dla społeczeństwa konsumpcyjnego zasada głosi, iż jego członków utrzymywać trzeba w stanie permanentnego niespełnienia. „To właśnie niemożność zaspokojenia pragnień oraz mocne i trwałe przekonanie, że każdy akt zaspokojenia pozostawia wciąż jeszcze wiele do życzenia i zasługuje na korektę, stanowią koło zamachowe prokonsumenckiej gospodarki" (Bauman 2007b, s. 126). Towar dający trwałą przyjemność hamuje obrót rynkowy, pozwala konsumentowi osiąść na laurach (tj. uznać, ze może ograniczyć wydawanie pieniędzy na nowe towary). Wychodząc z tego założenia Don Slater (1997, s. 100) twierdzi, iż satysfakcja konsumenta oznacza stagnację gospodarczą. Natomiast dobro, które nie przynosi spełnienia, albo też daje je na bardzo krótki moment, zmusza konsumenta do dalszego szukania odtrutki na ów stan. Używając kulinarnej metafory - najgorszy konsument to konsument syty, najlepszy to łakomy, raptem chwilę po zjedzeniu odczuwający głód, szybko nudzący się pochłanianymi potrawami i gotów jak najczęściej próbować nowego smakołyku. A ujmując rzecz bardziej dosłownie - najlepszy konsument to taki, który co rusz skłonny jest kwestionować zadowolenie nie tylko $z$ tego, co ma, ale także $z$ tego, kim jest oraz jak jest widziany (bo pamiętajmy, że on sam także stanowi przedmiot konsumpcji), czyli aktywnie poszukujący na rynku lekarstwa na swą niedolę. Społeczeństwo konsumpcyjne charakteryzuje „nieustająca presja, by stać się kimś innym, niż się jest, a rynki konsumpcyjne ogniskują uwagę na niezwłocznej deprecjacji swych wcześniejszych ofert, aby zrobić w popycie miejsce dla nowych. Rynki kultywują w konsumentach niezadowolenie $z$ produktów używanych dla zaspokojenia ich potrzeb - jak również niezadowolenie $z$ uzyskanej już tożsamości i z zestawu potrzeb, które tę tożsamość definiują" (Bauman 2009a, s. 108).

Najbardziej oczywistym sposobem utrzymywania konsumentów w stanie permanentnego niezaspokojenia jest „dezawuowanie i deprecjonowanie produktów konsumpcyjnych wkrótce po wprowadzeniu ich na orbitę konsumenckich pragnień" (Bauman 2007b, s. 126-127). W innym miejscu Bauman (2007a, s. 4) pisze o „pomniejszaniu, dewaluacji czy wręcz potępieniu produktu tuż po tym, jak kampania reklamowa zdołała uczynić go przedmiotem powszechnego pożądania”, nazywając to zjawisko „prestiżową dewaluacją”. Zwraca jednak uwagę, że istnieje „dyskretniejsza i skuteczniejsza metoda, polegająca na takim zaspokajaniu potrzeb/pragnień/zachcianek, by owo zaspokojenie rodziło nowe potrzeby/pragnienia/zachcianki" (Bauman 2007b, s. 127). Produkty projektowane są w taki sposób, by generowały nowe potrzeby (czy też - co daje w tym wypadku analogiczny efekt — odkrywały albo tworzyły jakieś braki w życiu konsumenta), a metodą na zaspokojenie owych potrzeb (czy też uzupełnienie braków) jest kolejna partia (również rozbudzająca nowe żądze / ujawniająca bądź kreująca następne niedostatki) dóbr. Współczesne firmy organizują towary w taki sposób, by kupno jednego zapraszało do naby- 
cia kolejnego, a także — by atrakcyjność większej ich partii wzrastała w sposób synergiczny. Najprostszy przykład to różnorodne gadżety oferowane dzieciom w seriach, choćby nawet kolekcje obrazków dodawanych do gum do żucia. Zdobycie ich jak największej liczby staje się przedmiotem rywalizacji między małymi konsumentami. Zebranie całej serii pozwala uzyskać jakąś nagrodę czy po prostu wypełnić cały album dołączony do danego produktu kompletem obrazków. To najbardziej banalny przykład marketingowego wykorzystania zasady serii. Dziś jest ona eksploatowana na mnóstwo innych sposobów w wielu obszarach handlu, które mają za cel wciągnięcie konsumenta w swoiste konsumpcyjne domino, tak by kupno jednego towaru implikowało sięgnięcie po następny, a potem kolejny itd.

Za realizację swoiście pojętego prawa towarowej serii uznać można konsumpcję mającą na celu zrekompensowanie starty poniesionej w wyniku wcześniejszego aktu konsumpcji. Sytuacja ta ma analogię w tzw. chorobach jatrogennych, czyli wywołanych przez wcześniejsze terapie (Bauman 2007b, s. 127). Bauman przytacza przykład epidemii nadwrażliwości skórnej spowodowanej nadużywaniem preparatów do pielęgnacji ciała, której leczenie wymaga kolejnych środków. Pojawianie się — realnych bądź urojonych — schorzeń będących skutkiem poprzedniej terapii gwarantuje nieustający popyt na produkty przemysłu farmaceutycznego. Ten terapeutyczny łańcuch staje się dla autora Ptynnego życia metaforą mechanizmów współczesnego rynku jako takiego. Zdaniem niektórych mamy do czynienia ze zjawiskiem bardziej złowrogim. Otóż konsument nakłaniany jest do spożywania produktów, które mu szkodzą, po to, by wykreować zapotrzebowanie na remedium (najlepiej takie, w które wpisane są działania uboczne, wymagające kolejnych, dostępnych na rynku środków zaradczych). Według tej zasady działać ma mechanizm karmienia społeczeństwa przyczyniającym się do otyłości jedzeniem (typu fast food), po to by stworzyć popyt na preparaty wspomagające odchudzanie, a także potężną ofertę doradztwa dietetycznego i treningowego. Zmanipulowany przez marketing, nierozważnie korzystający z tego typu produktów i usług konsument może popaść $\mathrm{z}$ kolei, jeśli nie $\mathrm{w}$ anoreksję, to $\mathrm{w}$ ortoreksję (obsesję na punkcie zdrowego odżywiania bądź określonej, ścisłej diety). Teza głosząca, że niszczenie zdrowia konsumenta jest zaplanowane, stanowi wynik świadomie zawiązanego spisku, wydaje się cokolwiek demagogiczna. W krytycznym wobec społeczeństwa konsumpcyjnego dyskursie nie brak jednak głosów, iż system podtrzymuje ten stan rzeczy, bo stanowi napęd rynku (Spurlock 2005, s. 247-276).

Z kolei Baudrillard generalną zasadę służącą utrzymywaniu konsumenta w poczuciu braku, niezaspokojenia widzi w nadawaniu kolejnym dobrom statusu rzadkości. Rzeczy powszechnie i bez ograniczeń osiągalne nie są przedmiotem pożądania, korzystanie $z$ nich jest naturalne, nie podlega problematyzowaniu i refleksji ${ }^{13}$. A co najważniejsze - nie da się ich utowarowić. Do-

13 Określamy je mianem dóbr wolnych (Bywalec, Rudnicki 2002, s. 34). 
piero świadomość ograniczonej dostępności, wizja utraty, wytwarza chęć ich zawłaszczenia. Społeczeństwo konsumpcyjne dąży do tego, by dobra dostępne w sposób nieskrępowany, swobodnie istniejące w otoczeniu człowieka stały się rzadkimi, właśnie po to, by uczynić z nich towary. Po części jest to wynik realnie kurczącego się zasobu takich dóbr. Zanieczyszczenie uczyniło z powietrza poniekąd luksusowy towar z jego czystej postaci (urlopowicze płacą przecież za możliwość oddychania świeżym powietrzem w pozamiejskich kurortach). Innym przykładem jest utowarowienie dobra tak fundamentalnie naturalnego jak naturalna przyroda - wszak wstęp do wielu rezerwatów przyrody czy parków narodowych jest płatny (a bliskość zieleni czy zwykłego miejskiego parku stanowi element zawyżający cenę mieszkania $\mathrm{w}$ zatłoczonych metropoliach). Podobnie rzecz ma się z ciszą - brak hałasu we współczesnym wielkomiejskim środowisku także ma swą cenę. Społeczeństwo konsumpcyjne musi jedynie uzmysłowić konsumentowi ich rzadkość. Czyni się to między innymi przez odpowiedni dyskurs, informujący o prawie do danego dobra - dyskurs przewrotny, bo przyznanie kolejnych praw powinno świadczyć o poszerzaniu sfery wolności jednostki, a tak naprawdę służy zwróceniu uwagi właśnie na ograniczoną dostępność tego czegoś, co jest przedmiotem ustaleń. „Prawo do przestrzeni istnieje dopiero od chwili, w której brakuje już przestrzeni dostępnej wszystkim i gdy przestrzeń [...] staje się przywilejem niektórych kosztem innych” (Baudrillard 2006, s. 59). Z kolei „prawo do czystego powietrza oznacza utratę (zanik) czystego powietrza jako dobra naturalnego, osiągnięcie przezeń statusu towaru oraz jego nierówną redystrybucję społeczną" (Baudrillard 2006, s. 60). Owo przyznawanie kolejnych uprawnień to zatem nie wyraz realnego postępu społecznego $\mathrm{w}$ znaczeniu poszerzenia przestrzeni czy intensyfikacji procesu emancypacji, lecz jedynie przejaw rozwoju społeczeństwa konsumpcyjnego, w którego logikę wpisana jest transformacja „naturalnych wartości” w źródła „zysku ekonomicznego i społecznego przywileju” (Baudrillard 2006, s. 60).

Często rzadkość uzmysławiana jest także poprzez uświadomienie nieszczęść, jakie mogą człowieka spotkać i fatalnych konsekwencji niepoddania się odpowiedniej profilaktyce. Pragnienie wywoływane jest w trybie pogróżki — jeśli nie wypełnisz zaleceń, co wiąże się z określonymi zachowaniami konsumpcyjnymi, narażasz się na ryzyko. W tym sensie dobrem rzadkim staje się choćby brak nowotworu czy wyjście bez szwanku z wypadku samochodowego - tak oto otwiera się ogromny rynek środków mających chronić nas przed rzeczoną chorobą albo kosztownych zabezpieczeń stosowanych w autach. Większość ludzi na co dzień nie myśli o przywoływanych w tych sformułowaniach dramatach, niedoświadczanie ich jest stanem naturalnym (tak jak cisza i las były niegdyś dobrami naturalnymi i wolnymi), dopiero wyartykułowanie zagrożenia uświadamia „rzadkość” tegoż stanu. Ten mechanizm to ogromne pole działania dla rynku - wszak liczba możliwych zagrożeń czyhających na ludzi jest nieskończona, więc liczba potrzeb związanych z zabezpieczeniem się przed 
nimi i służących temu celowi produktów także ${ }^{14}$. Złożoność dzisiejszego świata nie pozwala na samodzielną ocenę owych niebezpieczeństw, a więc konsument zdany jest na eksperta - jedną z centralnych figur społeczeństwa konsumpcyjnego. Jest on podstawową instytucją uświadamiającą rzadkość i legitymizującą poczucie braku, a tym samym utrzymującą konsumenta w stanie ciągłego niezaspokojenia. Tak oto „pochłania nas tropienie siedmiu znaków choroby nowotworowej, lub pięciu symptomów depresji albo egzorcyzmowanie widma wysokiego ciśnienia, podwyższonego poziomu cholesterolu, stresu lub otyłości [...]. Ci, którzy mogą sobie na to pozwolić, zabezpieczają się przed wszelkimi widzialnymi i niewidzialnymi, aktualnymi i przewidywanymi, znanymi i nieznanymi, rozproszonymi, lecz wszechobecnymi zagrożeniami" (Bauman 2007b, s, 108). Zagrożeń jednak nieustannie przybywa. „Bezpieczeństwo osobiste stało się głównym elementem wszelkiego typu strategii marketingowych” - diagnozuje Bauman (2007b, s. 110).

Społeczeństwo konsumpcyjne jest zatem zdominowane przez kategorię rzadkości (Baudrillard 2006, s. 73). Zasada systemu „sprowadza się do zagwarantowania sobie przeżycia, a jego strategią w tym zakresie jest utrzymanie społeczeństwa w stanie niepewności, braku równowagi i ciągłego deficytu" (Baudrillard 2006, s. 55). Taka forma społeczeństwa nie ma nic wspólnego ze społeczeństwem dobrobytu. Produkcja rzadkości, a co za tym idzie, poczucia niedostatku, stanowi jego napęd. Im więcej obszarów podlega temu procesowi, tym większa odległość dzieli konsumentów od założonego przez nich, dającego nadzieję na spełnienie celu; nadrabianie tego dystansu zawsze będzie wolniejsze od uciekania celu (tj. postępu procesu „urzadkowienia”), dlatego nie ma szans na zbliżenie się do stanu satysfakcji. W konsekwencji zaspokojone zostają nie potrzeby samych konsumentów, lecz potrzeby systemu. „Jasnym staje się, że stan dobrobytu oddala się w sposób nieuchronny, a wręcz zostaje on zanegowany i odrzucony na rzecz zorganizowanego panowania rzadkości" (Baudrillard 2006, s. 73). Paradoksalnie można przyjąć, że dobrobyt (a z pewnością o wiele wyższy stan zaspokojenia) był udziałem społeczeństw przedkapitalistycznych - pomimo ich, patrząc z obecnej perspektywy, obiektywnego niedostatku. Członkowie społeczeństw dawnych, które nie znały nawet pojęcia własności, racjonalnego rachunku ekonomicznego, były wolne od jarzma nadawania statusu rzadkości wszystkiemu, co ich otacza.

System nie dopuszcza więc do osiągnięcia stanu satysfakcji przez konsumenta, stosując praktyki deprecjonowania skonsumowanych dóbr i ciągłego rozbudzania poczucia braku. Sam stan satysfakcji — jeśli jakiemuś konsumentowi, choćby na chwilę jednak uda się go osiągnąć - surowo potępia. Wszak

14 Marek Krajewski (2005, s. 223) pisze: „jedną z podstawowych i rejestrowanych w badaniach konsumenckich motywacji klientów jest dziś kupowanie takich obiektów, które zwiększają poczucie osobistego bezpieczeństwa i minimalizują ryzyka". Konsumpcja w coraz większym stopniu koncentruje się na „minimalizowaniu skutków oddziaływania środowiska zewnętrznego, które definiowane jest jako opresyjne, niebezpieczne, streso- i chorobogenne". 
nasycenie oznacza zastój w rozwijaniu indywidualnego projektu życia, który przecież powinien bazować na ciągłym uczeniu się, samodoskonaleniu, gromadzeniu kolejnych doświadczeń i doznań (to obowiązki konsumentów, które jednak przedstawiane są im jako przywileje); jednym słowem — życie nudne, bezbarwne. Socjalizowani w takim etosie konsumenci są gotowi uznać poczucie spełnienia za coś wstydliwego, w konsekwencji skazującego ich nawet na społeczne wykluczenie. „Te jednostki, które zadowalają się skończonym zbiorem potrzeb, [...] są wadliwymi konsumentami - to znaczy specyficzną dla społeczeństwa konsumentów odmianą wyrzutków społecznych. Groźba i strach przed ostracyzmem i wydaleniem unoszą się również nad tymi, którzy czują się zaspokojeni posiadaną tożsamością i którzy zadowolą się tym, za co ich uznają ci inni, którzy się liczą" (Bauman 2009a, s. 108). Zaspokojenie ma wpędzać konsumenta w poczucie winy, budzić przekonanie o stagnacji i marazmie. To sytuacja zgoła paradoksalna, bo oznacza ona, iż konsumenci mają być niezadowoleni $z$ bycia zadowolonymi, a trwałą satysfakcję, spełnienie traktować jako przejaw życiowej klęski. Można by rzec, że funkcjonujący w takim systemie konsument internalizuje potrzebę poszukiwania braku, staje się ona jego napędem życiowym. „Braki, zarówno te znane, jak i te, które (nieuchronnie) dopiero się ujawnią, są przecież zapowiedzią rychłej odnowy i rychłego ożywienia, są obietnicą nowych przygód, nowych wrażeń i nowych rozkoszy" (Bauman 2007b, s. 132). Właśnie poszukiwanie, a nie znalezienie, staje się celem samym w sobie i podstawowym źródłem przyjemności, jej istotą. „Dla konsumentów $\mathrm{w}$ społeczeństwie konsumpcyjnym bycie $\mathrm{w}$ ruchu — pogoń, poszukiwanie, nieznalezienie, a właściwie nieznalezienie jeszcze - to nie dolegliwości, lecz obietnica rozkoszy, a może wręcz sama rozkosz" (Bauman 2000a, s. 99). Konsument tęskni do głodu, który da mu motywację do działania. O to właśnie chodzi w słowach, iż konsument pożąda samego pożądania. „Pożądanie pożąda pożądania. [...] Możliwość, że w zasięgu wzroku nie będzie niczego, co potrafiłoby je rozbudzić na nowo; wizja, że będzie się wydanym światu, gdzie nie ma nic, czego by można było pożądać - musi być dla idealnego konsumenta ponurym horrorem (i oczywiście koszmarem straszącym po nocach sprzedawców dóbr konsumpcyjnych)" (Bauman 2000a, s. 99).

$*$

Podstawowa teza Baumana - mówiąca, iż konsumpcyjna wydajność stała się ostatecznym, rozstrzygającym kryterium przynależności do społeczeństwa, wskazującym w nim miejsce - jest zbyt jednostronna i radykalna. Weźmy trywialny przykład - osoby podejrzewane o terroryzm czy jawny zwolennik i propagator określonych ideologii (choćby faszystowskiej), nawet legitymizujący się ogromnymi możliwościami konsumpcyjnymi, nie będą zapewne witani $\mathrm{w}$ granicach współczesnych zachodnich krajów $z$ otwartymi ramionami. Wciąż wiele spośród tych państw przyjmuje imigrantów przede wszystkim jako tanie źródło siły roboczej, a nie ze względu na ich siłę konsumpcyjną. W wizji 
kreślonej przez socjologa tradycyjne instytucje polityczne stały się po prostu agendami wykonawczymi jedynego prawdziwego suwerena - rynku. Jakkolwiek zgodzić się trzeba, że rynek w ogromnym stopniu kształtuje panujący ład i stosunki międzyludzkie, to wbrew rysowanemu przez Baumana apokaliptycznemu obrazowi nie sposób uznać, że konsumpcjonizm po prostu zastąpił politykę czy stał się jedyną obowiązującą polityką. Zatem konstatacja, iż rynek podporządkował sobie wszelkie inne formy regulacji społecznej, wydaje się nadmiernie redukcjonistyczna - jakkolwiek przez wielu autorów jest ona ochoczo powtarzana (Barber 2008, s. 30-40; Kuttner 1997, s. 3).

$\mathrm{W}$ realiach postępującego utowarowienia - co jest niewątpliwie faktem i co stanowi główny punkt ataku krytyków społeczeństwa konsumpcyjnego, zwłaszcza marksistowsko zorientowanych - tym bardziej warto zastanowić się, czy istnieją i gdzie leżą, czy też gdzie należałoby postawić, jego granice. Zadania tego podejmuje się Michael Sandel (2012). Nie daje wprost odpowiedzi na pytanie o granice utowarowienia. Twierdzi natomiast, że problem ten powinien być kluczowym elementem debaty społecznej. Ta wymaga istnienia realnej sfery publicznej ${ }^{15}$ (czy też przestrzeni publicznej ${ }^{16}$ ). Stanowi ona warunek sine qua non podmiotowości społeczeństwa. Sandel podaje wiele przykładów dobitnie ilustrujących twierdzenie o komercjalizacji opanowującej coraz szczelniej rzeczywistość społeczną, wnikającej we wszelkiego typu praktyki (sprzedawanie przez londyńską agencję powierzchni reklamowej na ludzkich czołach, na których umieszcza się zmywalne tatuaże, handel polisami na życie osób ciężko chorych, możliwość korzystania za odpowiednią opłatą z pasa szybkiego ruchu w godzinach szczytu w amerykańskim Minneapolis czy wykupienia przez skazanych przestępców celi o wyższym standardzie w więzieniu w Kalifornii). Jednocześnie odnotowuje, że handlu wieloma dobrami zabrania prawo, na przykład handlu dziećmi (przynajmniej w większości państw zachodnich), organami do przeszczepu czy głosami wyborczymi. A to dlatego, że z obrotu rynkowego wyłączony jest człowiek (Baumanowska koncepcja jego utowarowienia nie ma wszak sensu dosłownego). Zdaniem Sandela, we współczesnych zachodnich demokracjach istnieje także nadal zarezerwowana dla działań obywatelskich, nieodzowna dla demokracji przestrzeń publiczna, jakkolwiek ulega ona erozji. Można też przyjąć, że wielu cennych w życiu rzeczy, być może najcenniejszych, nie da się kupić za pieniądze, bo ich istota opiera się w znacznej mierze na

15 Kategoria sfery publicznej, jej pożądany i możliwy kształt, jest w socjologii obszarem sporów. Zawsze jednak wskazuje się, że jej podstawą jest możliwość otwartej dla wszystkich, wolnej debaty nad istotnymi dla danej społeczności kwestiami. Jest to obszar, w którym jednostka realizuje się jako obywatel. Klasyczny pogląd na sferę publiczną zob. Habermas 2007.

16 Rozróżnienie między sferą a przestrzenią publiczną wprowadza Chantal Mouffe. Pierwszą wiąże ściśle $z$ koncepcją Jürgena Habermasa, który wierzy w wypracowanie uniwersalnych reguł, racjonalność debatujących podmiotów i osiągnięcie konsensusu. Z kolei przestrzeń publiczna jest obszarem wolnej, otwartej ekspresji, bazuje na artykulacji antagonizmów, permanentnym konflikcie, zmierzającym nie do konsensusu, lecz do zdobycia hegemonii (Carpentier, Cammaerts 2006; Mouffe 2005). 
tej właśnie nieredukowalności - weźmy miłość, przyjaźń czy Nagrodę Nobla (oczywiście pieniądze mogą pomóc $w$ ich zdobyciu, ale żadna $z$ nich nie ma konkretnej wartości wymiennej). Trzeba również zauważyć, że w wielu obszarach życia obowiązujące powszechnie normy społeczne i wartości wciąż okazują się regulatorem skuteczniejszym od pieniądza - jest to oczywiste wśród ludzi, między którymi istnieją osobiste więzi (rodzina, kręgi przyjacielskie), a także w przypadku osób powiązanych bardziej zdepersonalizowanymi relacjami ${ }^{17}$.

Utowarowienie ma więc dziś niewątpliwie granice, istnieją konkurencyjne wobec rynku i wygrywające z nim formy regulacji życia społecznego. Nie można jednak wykluczyć, że galopująca komercjalizacja owe granice przesunie ${ }^{18}$.

\section{BIBLIOGRAFIA}

Attali Jacques, 2008, Krótka historia przysztości, tłum. Wojciech Nowicki, Prószyński i S-ka, Warszawa.

Barber Benjamin R., 2008, Skonsumowani. Jak rynek psuje dzieci, infantylizuje dorostych i potyka obywateli, tłum. Hanna Jankowska, Muza, Warszawa.

Baudrillard Jean, 2006, Społeczeństwo konsumpcyjne. Jego mity i struktury, tłum. Sławomir Królak, Sic!, Warszawa.

Bauman Zygmunt, 1995, Wolność, tłum. Joanna Tokarska-Bakir, Znak-Fundacja im. Stefana Batorego, Kraków-Warszawa.

Bauman Zygmunt, 1996, Socjologia, tłum. Jerzy Łoziński, Zysk i S-ka, Poznań.

Bauman Zygmunt, 2000a, Globalizacja. I co z tego dla ludzi wynika, tłum. Ewa Klekot, PIW, Warszawa.

Bauman Zygmunt, 2000b, Ponowoczesność jako źródto cierpień, Sic!, Warszawa.

Bauman Zygmunt, 2004, Życie na przemiat, tłum. Tomasz Kunz, Wydawnictwo Literackie, Kraków.

Bauman Zygmunt, 2006a, Praca, konsumpcjonizm i nowi ubodzy, tłum. Stanisław Obirek, WAM, Kraków.

Bauman Zygmunt, 2006b, Społeczeństwo w stanie oblężenia, tłum. Janusz Margański, Sic!, Warszawa.

Bauman Zygmunt, 2007a, Konsumenci w spoteczeństwie konsumentów, Wydawnictwo Uniwersytetu Łódzkiego, Łódź.

Bauman Zygmunt, 2007b, Ptynne życie, tłum. Tomasz Kunz, Wydawnictwo Literackie, Kraków.

Bauman Zygmunt, 2009a, Konsumowanie życia, tłum. Monika Wyrwas-Wiśniewska, Wydawnictwo Uniwersytetu Jagiellońskiego, Kraków.

Bauman Zygmunt, 2009b, Nowoczesność i Zagłada, tłum. Tomasz Kunz, Wydawnictwo Literackie, Kraków.

Bauman Zygmunt, 2011, O zamieszkach londyńskich, czyli konsumeryzm zbiera swoje owoce, przedruk wywiadu na stronie „Dziennik Opinii. Krytyka Polityczna” (http://www.krytykapolityczna. $\mathrm{pl} /$ Opinie/BaumanOzamiszkachlondynskichczylikonsumeryzmzbieraswojeowoce/menuid-19 7.html).

Bombol Małgorzata, Dąbrowska Anna, 2003, Czas wolny. Konsument, rynek, marketing, K.E. Liber, Warszawa.

Bywalec Czesław, Rudnicki Leszek, 2002, Konsumpcja, Polskie Wydawnictwo Ekonomiczne, Warszawa.

$17 \mathrm{Z}$ barku miejsca po przykłady odsyłam do książki Sandela.

18 Sugestywna antyutopia wszechrynku, a więc opis możliwego kształtu przyszłego świata totalnie podporządkowanego władzy rynku znajduje się w: Attali 2008. 
Carpentier Nico, Cammaerts Bart, 2006, Hegemony, Democracy, Agonism and Journalism: An Interview with Chantal Mouffe, „Journalism Studies”, t. 7, nr 6.

Foucault Michel, 1993, Nadzorować i karać. Narodziny więzienia, tłum. Tadeusz Komendant, Aletheia, Warszawa.

Grzeszczyk Ewa, 2004, Amerykańskie wzory konsumpcyjne, „Kultura i Społeczeństwo”, nr 4.

Habermas Jürgen, 2007, Strukturalne przeobrażenia sfery publicznej, tłum. Wanda Lipnik, Małgorzata Łukasiewicz, Wydawnictwo Naukowe PWN, Warszawa.

Hostyński Lesław, 2006, Wartości w świecie konsumpcji, Wydawnictwo Uniwersytetu Marii Curie-Skłodowskiej, Lublin.

Krajewski Marek, 1997, Konsumpcja i wspótczesność. O pewnej perspektywie rozumienia świata społecznego, „Kultura i Społeczeństwo”, nr 3.

Krajewski Marek, 2005, Co dziś konsumujemy? Socjologia przedmiotów, w: Aldona Jawłowska, Marian Kempny (red.), Konsumpcja — istotny wymiar globalizacji kulturowej, IFIS PAN, Warszawa.

Kuttner Robert, 1997, Everything for Sale, Alfred A. Knopf, New York.

Mouffe Chantal, 2005, Agonistyczne przestrzenie publiczne i polityka demokratyczna, tłum. Jakub Maciejczyk (http://recyklingidei.pl/mouffe-agonistyczne-przestrzenie-publiczne-polityka-demokra tyczna).

Mróz Bogdan, 2009, Consumo ergo sum? Rola konsumpcjonizmu we wspótczesnych społeczeństwach, w: Bogdan Mróz (red.), Oblicza konsumpcjonizmu, SGH, Warszawa.

Reynolds Simon, 2011, Retromania: Pop Culture's Addiction to Its Own Past, Faber \& Faber, London.

Sandel Michael J., 2012, Czego nie można kupić za pieniądze. Moralne granice rynku, tłum. Anna Chromik, Tomasz Sikora, Kurhaus, Warszawa.

Siuda Piotr, 2012, Kolekcjonowanie kontra szybkie konsumowanie, „Przegląd Socjologii Jakościowej”, nr 3.

Slater Don, 1997, Consumer Culture and Modernity, Polity, Cambridge.

Smyczek Sławomir, Sowa Izabela, 2005, Konsument na rynku — zachowania, modele, aplikacje, Difin, Warszawa.

Spurlock Morgan, 2005, Życie w fast foodzie — co czeka McCzłowieka, tłum. Tomasz Misiorek, Helion, Gliwice.

Weber Max, 1985, Obiektywność poznania w naukach spotecznych, w: Andrzej Chmielecki i in., Problemy socjologii wiedzy, Państwowe Wydawnictwo Naukowe, Warszawa.

\section{ZYGMUNT BAUMAN ON CONSUMER SOCIETY}

\section{Summary}

The aim of this article is to analyze the concept of a consumer society, based primarily on the work of Zygmunt Bauman. Bauman's works synthesize and modernize previous ideas about this type of society. The article presents the most important of Bauman's thoughts on the issue, including the imperative of choice, the totality of commodification, praise for transience, and permanent insatiety. These ideas are subjected to critical analysis and illustrated with examples drawn from existing sources and the author's own observations.

\section{Key words/słowa kluczowe}

Zygmunt Bauman; consumer society / społeczeństwo konsumpcyjne; consumption / konsumpcja; market / rynek 